Short Communication

\title{
Investigation of $\mathrm{M}_{2} \mathrm{HPO}_{4}\left(\mathrm{M}=\mathrm{K}^{+}, \mathrm{Na}^{+}\right)$as Electrolyte for Alkaline Fuel Cell Working with Oxygen Containing Carbon Dioxide
}

\author{
Guogang Xue, ${ }^{1, *}$ Jian $\mathrm{Gao}^{2}, \mathrm{Min} \mathrm{Yun}^{3}$, Dan $\mathrm{Hu}^{3}$, Jianguo $\mathrm{Wu}^{3}$ \\ ${ }^{1}$ Jiangsu Key Laboratory of Advanced Laser Materials and Devices, School of Physics and Electronic \\ Engineering, Jiangsu Normal University, Xuzhou 221116, P.R. China \\ ${ }^{2}$ School of Environmental and Chemical Engineering, Tianjin Polytechnic University, Tianjin 300387, \\ P.R. China \\ ${ }^{3}$ Wuxi Test Center of Supervision \& Inspection on Product Quality, Wuxi 214101, P.R. China \\ *E-mail: ggxue@jsnu.edu.cn
}

doi: $10.20964 / 110402734$

Received: 2 January 2016 / Accepted: 3 February 2016 / Published: 1 March 2016

\begin{abstract}
Basic salt of hydrogen phosphate $\left(\mathrm{M}_{2} \mathrm{HPO}_{4}\right)$ was investigated as electrolyte for alkaline fuel cell (AFC). A maximum power density (MPD) of $60 \mathrm{~mW} \mathrm{~cm}$ was obtained with $\mathrm{K}_{2} \mathrm{HPO}_{4}$ saturated solvent at room temperature, and a MPD of $30 \mathrm{~mW} \mathrm{~cm}{ }^{-2}$ was observed with $\mathrm{Na}_{2} \mathrm{HPO}_{4}$. The fuel cell with $\mathrm{K}_{2} \mathrm{HO}_{4}$ can work at least 3600 s without significant performance decrease. More interestingly, the electrolyte shows considerable $\mathrm{CO}_{2}$ tolerance since no obvious performance drop was observed when $\mathrm{CO}_{2}$ of purity of $99 \%$ was introduced into the oxygen stream. The results may provide an alternative way to develop electrolyte for AFC that is tolerant to $\mathrm{CO}_{2}$.
\end{abstract}

Keywords: alkaline, electrolyte, fuel cell, hydrogen phosphate

\section{FULL TEXT}

(C) 2016 The Authors. Published by ESG (www.electrochemsci.org). This article is an open access article distributed under the terms and conditions of the Creative Commons Attribution license (http://creativecommons.org/licenses/by/4.0/). 